\title{
Teaching Economics To The Best Undergraduates: What Are The Problems?
}

Giuliana Campanelli Andreopoulos, William Paterson University, USA Alexandros Panayides, William Paterson University, USA

\begin{abstract}
Economics is usually perceived as a difficult subject among undergraduate students with negative repercussions on their performance. The literature suggests that the students' problems with principles of economics are mainly related to the style and method of teaching together with the course content. Particularly attacked are the chalk and talk type of teaching, the simplicity of economic models, the lack of discussion on current issues, and diversity. In a previous investigation we tried to shed some light on this debate by directly asking students for their opinions on the way introductory economics is taught and we arrived at some unexpected results. The present paper is an extension of our previous study by looking at a further dimension which can be crucial for the explanation of the results: students' GPA and we selected the best students.
\end{abstract}

\section{INTRODUCTION AND SUMMARY OF THE LITERATURE}

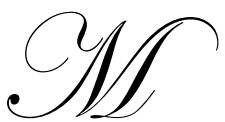

any students continue to perceive economics as a difficult subject with negative repercussions on their performance. For many years, economists and their main institution, The American Economic Association, have been trying to understand this phenomenon and to make economics more appealing, particularly in the introductory courses, Jensen and Owen (2003), Lee, Salemi and Siegfried (2002), Bartlett (1995), and Walstad and Saunders (1998). The vast majority of the literature seems to suggest that the style and the method of teaching together with the course content are the crucial reasons for this result, Becker (2001). Particularly attacked are the chalk and talk type of teaching, the simplicity of economic models, the lack of discussion on current issues, Becker (2001, 1997, \& 1996), and diversity and discrimination, Feiner and Roberts (2003) and Tuma (2003). Even though these explanations are appealing to instructors, we felt that they needed to be verified from the students' side. Therefore we decided to directly ask the students their opinion on the way introductory economics is and should be taught. Scope of this paper is to shed some light on the debate on teaching introductory economics by directly reporting the students' views. The present paper is an extension of our previous study by looking at a further dimension which can be crucial for the explanations of the results: student's GPA. More specifically we focus attention on the best students defined as those with a GPA equal of greater than 3.5 out 4. The basic idea is that good students are very demanding on the type of teaching as well as on the course content. Researches on educational practices in general suggest that they do not like passive method like the chalk and talk and the oversimplifications of many economic models, Jensen and Owen (2003).

\section{EMPIRICAL INVESTIGATION}

\section{Data Sample}

Our empirical investigation is based on students who attended principles of Macroeconomics and Microeconomics at the William Paterson University (WPU) in the period from fall 2008 to spring 2009 (two semesters) resulting in 79 responses from the principles of Microeconomics and 101 from the principles of Macroeconomics.

In 2008, the first year of our investigation, the total number of undergraduate students was 8,741 of which 1,627 were enrolled in the college of business. The demographic data of students attending WPU can be summarized as follows: (a) Student body profile by gender: Females 55.6\% and males $44.4 \%$; (b) Student body profile by 
ethnicity: As Table 1 shows, Whites are the majority of the student body followed by Hispanics and African Americans. It is worth noting that WPU recruits are almost all full time first year students from the state of New Jersey.

Table 1

Enrolled Students by Ethnicity, Fall 2008

\begin{tabular}{|l|c|c|}
\hline & Number & Percentage \\
\hline African American & 1,217 & 13.9 \\
\hline Asian & 512 & 5.9 \\
\hline Hispanic/Latino & 1,581 & 18.1 \\
\hline Native American & 11 & 0.1 \\
\hline Nonresident/Alien & 78 & 0.9 \\
\hline White & 4,634 & 53 \\
\hline Unknown/Other & 708 & 8.1 \\
\hline Total & $\mathbf{8 , 7 4 1}$ & $\mathbf{1 0 0}$ \\
\hline
\end{tabular}

\section{Questionnaire}

The study was conducted by using a questionnaire, distributed to students in the classroom (the questionnaire can be found in the appendix). The first part of the questionnaire dealt with the methods of teaching economic principles. In particular, we asked students to comment on the following methods of teaching: Chalk and talk type of lecture, teaching with technological tools, teaching with student interaction, a combination of all of the above, and on line courses. The second part of the questionnaire dealt with current economic issues and, more specifically, we asked students whether current economic issues should be discussed at greater length in class and (in their opinion) which ones. The remaining sections of the questionnaire, parts three through six dealt with other aspects discussed in the literature such as: connections between the course and everyday life decisions, the relationship between the simplicity of economic models and the understanding of the subject, the introduction of issues such as race, gender and other types of diversity into principles courses. Finally, we asked students to offer possible suggestions on how to improve the teaching of introductory economics.

We categorized the answers in the first part of the questionnaire as follows: Like, don't like and indifferent. In sections two through five we grouped the answers into the Yes and No categories. For section five we summarized the most common suggestions.

For the purpose of this investigation we report the results on four issues: chalk and talk type of lecture, the simplicity of economic models, current issues, and diversity. These are the main explanatory variables stated in the literature for the lack of interest in economics and a consequent negative performance in the subject.

\section{Results}

First, on the chalk and talk type of lecture, the main results are presented in Table 2:

Table 2

Chalk and Talk

\begin{tabular}{|l|c|c|}
\hline & Microeconomics & Macroeconomics \\
\hline & Percent & Percent \\
\hline Positive Answers & 69 & 14 \\
\hline Negative Answers & 16 & - \\
\hline No answer & 5 & 10 \\
\hline Unclear/Impossible to read answer & 10 & 16 \\
\hline
\end{tabular}


Surprisingly almost $72 \%$ of the students in both micro and macro perceive the chalk and talk type of lecture as very effective. The main reason seems to be that they are able to visualize the main concepts rather than just listen to the results. This result is unexpected because in the literature the chalk and talk method of teaching is assumed to be very boring and does not encourage classroom discussion, Becker (2001). Nevertheless, we should add that several good students stated that this method might get boring depending on the type of the instructor. Thus, one may say that it is the type of instructor rather than the type of teaching which is crucial for this result.

Following the discussion in the literature, we also asked the students whether they think that the simplicity of economic models renders their understanding of economics easier. The results are summarized in Table 3.

Table 3

Simplicity of Economic Models

\begin{tabular}{|l|c|c|}
\hline & Microeconomics & Macroeconomics \\
\hline & Percent & Percent \\
\hline Positive Answers & 73 & - \\
\hline Negative Answers & 1 & 5 \\
\hline No answer & 16 & 5 \\
\hline Unclear/Impossible to read answer & - & 5 \\
\hline
\end{tabular}

Once again, we found an unexpected result. Contrary to the literature, Becker (2001), that emphasizes the shortcomings of simplistic analysis, more than $80 \%$ of the students like the simplicity of economic models, particularly high is the figure for the macroeconomics classes. The main explanation for this result is that the students seem to establish a connection between the simplicity of the model and its graphical representation which helps them to immediately grasp its economic meaning.

We also asked the students whether or not current economic issues should be discussed at greater length in class. The results are summarized in Table 4.

Table 4

Longer Discussion on Current Economic Issues

\begin{tabular}{|l|c|c|}
\hline & Microeconomics & Macroeconomics \\
\hline & Percent & 80 \\
\hline Positive Answers & 84 & 10 \\
\hline Negative Answers & 10 & 10 \\
\hline No answer & 6 & - \\
\hline Unclear/Impossible to read answer & - & \\
\hline
\end{tabular}

This time our results seem to confirm the literature that students are willing to discuss more current issues. The reason for this result seems to be that students want real world applications of the material covered in class.

Moreover, as one can see from Table 4, our questionnaire provides an additional result: micro students are more willing to discuss current issues than the macro students. The divergence in the result is approximately 4 percentage points. We believe that the main reason for this result is that current issues are more extensively discussed in macroeconomics as part of the course content.

Finally, we asked the students whether issues about race, gender and other types of diversity should receive greater attention in the class. The results are summarized in table 5.

Surprisingly the data show that students do not like the idea of greater attention to issues like gender, race and other types of diversity. On the basis on the qualitative answers we have received it seems that even the best students expect from their first economics course, a business/technical content type of course with little or no discussion about social issues. 
Table 5

Greater Attention to Race, Gender and Other Types of Diversity

\begin{tabular}{|l|c|c|}
\hline & Microeconomics & Macroeconomics \\
\hline & Percent & 25 \\
\hline Positive Answers & 31 & 63 \\
\hline Negative Answers & 63 & 6 \\
\hline No answer & 6 & 6 \\
\hline Unclear/Impossible to read answer & - & \\
\hline
\end{tabular}

\section{CONCLUSIONS}

In this paper we tried to shed some light on the debate on what is wrong with the teaching of introductory economics by asking the students their opinions. In particular, we extended our previous investigation in trying to understand the perception of the best students about chalk and talk type of teaching, the simplicity of economics models, and the lack of discussion on current economic issues, and diversity in foundation courses. We carried an empirical investigation based on a questionnaire to WPU students in both micro and macro economics over the 2008-2009 academic year. Three of the four unexpected results we found in the previous investigation are confirmed. Even the best students like the chalk and talk type of teaching, the simplicity of economic models and they don't like any additional discussion on gender, race and diversity. However, several of the best students admitted that the chalk and talk can be boring, particularly if the instructor is boring. Thus, the type of instructor rather that the type of teaching seems to be crucial. Turning to the current economic issues, the best students once again confirm our previous result as well as the one of the literature: they would like to discuss them at greater length.

\section{REFERENCES}

1. Andreopoulos, G., and A. Panayides (2008). Teaching Economics to Undergraduates: What are the Problems? International Journal of Education Research. Vol. 3 (1), 2008.

2. Bartlett, R. L. (1995). Attracting "Otherwise Bright Students" to Economics 101. American Economic Review, 85, 362-366.

3. Becker, W. E. (2001). How to Make Economics the Sexy Science. The Chronicle of Higher Education, B10-B12.

4. Becker, W. E. (1997). Teaching Economics to Undergraduates. Journal of Economic Literature, 35, 13471373.

5. Becker, W. E., \& Watts, M. (1996). Chalk and Talk: A National Survey on Teaching Undergraduate Economics. American Economic Review, 86, 448-453.

6. Feiner, S., \& Roberts, B. (1995). Using Alternative Paradigms to Teach About Race and Gender: A Critical Thinking Approach to Introductory Economics. American Economic Review, 85, 367-371.

7. Jensen, J. E., \& Owen, A. (2003). Appealing to Good Students in Introductory Economics. Journal of Economic Education, 32, 299-325.

8. Lee, W. H., Salemi, M. K., \& Siegfried, J. J. (2002). Promoting Economic Literacy in the Introductory Economics Courses. American Economic Review, 92, 463-472.

9. Siegfried, J. J. (2003). Trends in Undergraduate Economics Degrees, 1991 to 2002. Journal of Economic Education, 34, 291-294.

10. Siegfried, J. J. (2002). Trends in Undergraduate Economics Degrees, 1991 to 2001. Journal of Economic Education, 33, 291-294.

11. Siegfried, J. J., \& Round, D. (2001). International Trends in Economics Degrees During the 1990s. Journal of Economic Education, 32, 203-218.

12. Tuma, E. H. (1995). Macroeconomics and Discrimination in Teaching. American Economic Review, 85, 352-356.

13. Vascellaro, J. E. (2005). The Hot Major for Undergrads is Economics. The Wall Street Journal, July $5^{\text {th }}$.

14. Walstad, W. B., \& Saunders P. (1998). Teaching Undergraduate Economics: A Handbook for Instructors. New York: McGraw Hill. 


\section{APPENDIX}

Questionnaire

1. Personal Data
(a) Gender
(b) Student status
(c) Overall GPA

2. Comment on the following methods of teaching Economic Principles
(a) Chalk and talk type of lecture
(b) Teaching with technological tools
(c) Teaching with student interaction
(d) A combination of (a) - (c)
(e) On line courses

3. Should current economic issues be discussed at greater length in class and in your opinion which ones?

4. Do you see any connections between this course and your everyday life decisions?

5. Do you think the simplicity of models (graphical approach) renders your understanding of economics easier?

6. Do you think that issues about race, gender and other types of diversity should receive greater attention in the course?

7. What would you suggest to improve the teaching of Introductory Economics? 
NOTES 